\title{
Non-malignant superior vena cava syndrome in a patient with incidental diagnosis of a congenital vascular defect
}

\author{
Rafael García Carretero
}

Hospital Universitario de Mostoles, Mostoles, Madrid, Spain

Correspondence to Dr Rafael García Carretero, rgcarretero@salud.madrid.org

Accepted 23 January 2017

\section{CrossMark}

To cite: García Carretero R. BMJ Case Rep Published online: [please include Day Month Year] doi:10.1136/ bcr-2016-218844

\section{DESCRIPTION}

An 81-year-old patient came to our clinic referred by his general practitioner to assess the distension of the veins in the neck and chest (figure 1). $\mathrm{He}$ was asymptomatic, except for the swollen collateral veins in the chest wall. He had no dyspnoea, cough or facial oedema. He had a several-year history of progressively enlarging veins over the anterior chest wall (since the age of 30 years), but he had never sought medical advice. The rest of the physical examination was normal. A chest CT scan showed a persistent left superior vena cava draining into the coronary sinus, chronic thrombosis of the right superior vena cava and venous collateral circulation in the chest (figure 2). The radiologist labelled the thrombosis as chronic, given the decreased venous diameter and the calcified, dense, heterogeneous thrombus.

Persistent left superior vena cava is the most common variation of the thoracic venous system, but it is a rare congenital malformation, with a frequency of $\sim 0.3 \%$. It is considered an embryological remnant in which the left brachiocephalic vein did not fully develop, draining into the right atrium via

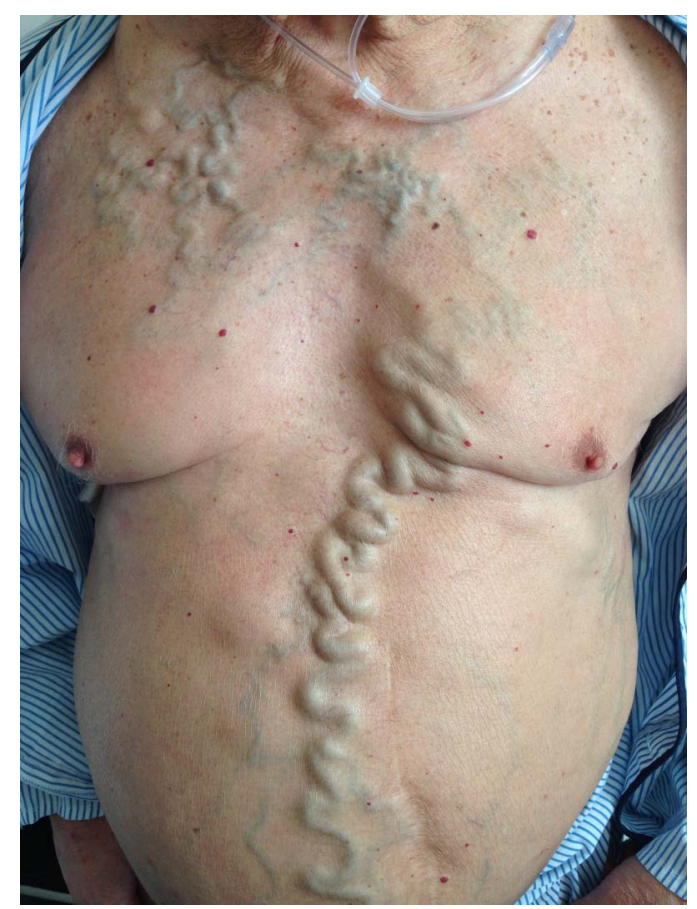

Figure 1 On physical examination, the patient presented with venous collateral circulation, shown as severe distension of the superficial veins in the chest wall.

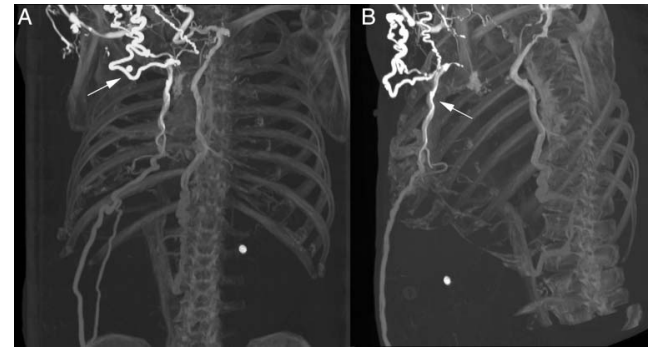

Figure 2 Chest CT scan reconstruction (Slide (A): coronal plane; Slide (B): sagittal plane) showing dilated veins (arrows), after intravenous contrast administration.

the coronary sinus. Persistent left superior vena cava can be associated with cardiac abnormalities, such as ventricular or atrioventricular septal defects, such as atrial septal defect, cor triatriatum valve, coarctation of aorta, coronary sinus ostial atresia and bicuspid aortic. ${ }^{1}$ Otherwise, it is a benign, asymptomatic condition and can be detected when imaging is performed for unrelated reasons. ${ }^{1}$ Isolated persistent left superior vena cava is a benign vascular anomaly and has no haemodynamic consequence. ${ }^{1}$

Our patient underwent a chest CT scan to assess the superior vena cava syndrome, which is caused by malignant conditions, such as lung cancer or lymphoma in more than $90 \%$ of cases. Infections such as tuberculosis, and extrinsic compression such as syphilitic aortic aneurysm, thymoma or thyroid goitre, are also known to cause superior vena cava syndrome. Thrombosis of the superior vena cava, however, is less common when it is not related to central venous catheters in the subclavian vein or the superior vena cava. ${ }^{2}$

Superior vena cava syndrome can be diagnosed on physical examination alone, but studies must be performed in order to establish a cause. The recruitment of venous collaterals depends on the rapidity of the onset of the obstruction. ${ }^{3}$ Our patient developed the symptoms over a period of years, which favours the diagnosis of a nonmalignant condition because the thrombus allowed enough time for such collateral flow to develop.

Our patient presented with chronic superior vena cava syndrome due to chronic thrombosis of the vena cava, which was not associated with a central venous catheter. The diagnosis of the persistent left superior vena cava was incidental. This malformation is not a predisposing factor for venous thrombosis or abnormalities in the development of the vena cava. 


\section{Learning points}

- Most cases of superior vena cava syndrome are caused by malignant conditions, especially lung cancer, as well as lymphoma. A diagnostic workup is essential to rule out those malignancies.

- Typical features of superior vena cava syndrome include dyspnoea, facial swelling, cough and upper limb, which may indicate the chronic onset (weeks) of the syndrome.

- Persistent left superior vena cava is a rare congenital abnormality, usually related to severe cardiac malformations and significant mortality and morbidity. Otherwise, the diagnosis is merely incidental and the clinical course is asymptomatic.
Twitter Follow Rafael García Carretero @rafa_linux

Acknowledgements The author would like to thank Jacqueline Lamb for her great support, suggestions and encouragement in the making of this manuscript; her advice and tips for British spelling were invaluable.

Competing interests None declared.

Patient consent Obtained.

Provenance and peer review Not commissioned; externally peer reviewed.

\section{REFERENCES}

1 Goyal SK, Punnam SR, Verma G, et al. Persistent left superior vena cava: a case report and review of literature. Cardiovasc Ultrasound 2008;6:50.

2 Nascimbene A, Angelini P. Superior vena cava thrombosis and paradoxical embolic stroke due to collateral drainage from the brachiocephalic vein to the left atrium. Tex Heart Inst J 2011;38:170-3.

3 Cohen R, Mena D, Carbajal-Mendoza R, et al. Superior vena cava syndrome: a medical emergency? Int J Angiol 2008:17:43-6.

Copyright 2017 BMJ Publishing Group. All rights reserved. For permission to reuse any of this content visit

http://group.bmj.com/group/rights-licensing/permissions.

BMJ Case Report Fellows may re-use this article for personal use and teaching without any further permission.

Become a Fellow of BMJ Case Reports today and you can:

- Submit as many cases as you like

- Enjoy fast sympathetic peer review and rapid publication of accepted articles

- Access all the published articles

- Re-use any of the published material for personal use and teaching without further permission

For information on Institutional Fellowships contact consortiasales@bmjgroup.com

Visit casereports.bmj.com for more articles like this and to become a Fellow 